\title{
Mast cells can promote the development of multiple features of chronic asthma in mice
}

\author{
Mang Yu, ${ }^{1}$ Mindy Tsai, ${ }^{1}$ See-Ying Tam, ${ }^{1}$ Carol Jones, ${ }^{1}$ James Zehnder, ${ }^{1}$ and Stephen J. Galli ${ }^{1,2}$ \\ 1Department of Pathology and 2Department of Microbiology and Immunology, Stanford University School of Medicine, Stanford, California, USA.
}

\begin{abstract}
Bronchial asthma, the most prevalent cause of significant respiratory morbidity in the developed world, typically is a chronic disorder associated with long-term changes in the airways. We developed a mouse model of chronic asthma that results in markedly increased numbers of airway mast cells, enhanced airway responses to methacholine or antigen, chronic inflammation including infiltration with eosinophils and lymphocytes, airway epithelial goblet cell hyperplasia, enhanced expression of the mucin genes $M u c 5 a c$ and $M u c 5 b$, and increased levels of lung collagen. Using mast cell-deficient $\left(K_{i t}{ }^{W-s h} / W-s h\right.$ and $/$ or $\left.K i t^{W / W-v}\right)$ mice engrafted with $F c R \gamma^{+/+}$or $F c R \gamma^{-/-}$mast cells, we found that mast cells were required for the full development of each of these features of the model. However, some features also were expressed, although usually at less than wild-type levels, in mice whose mast cells lacked $\mathrm{FcR} \gamma$ and therefore could not be activated by either antigen- and IgEdependent aggregation of Fc\&RI or the binding of antigen-IgG1 immune complexes to Fc $\gamma$ RIII. These findings demonstrate that mast cells can contribute to the development of multiple features of chronic asthma in mice and identify both $\mathrm{FcR} \gamma$-dependent and $\mathrm{FcR} \gamma$-independent pathways of mast cell activation as important for the expression of key features of this asthma model.
\end{abstract}

\section{Introduction}

Asthma is a complex inflammatory disorder that is becoming increasingly prevalent, particularly in the developed world (1-3). Once thought to be mainly a disorder of airway smooth muscle reactivity, asthma now is recognized to be a syndrome associated with persistent chronic inflammation of the airways (1-3). It has also become apparent that long-standing asthma can result in changes in the airways themselves, called "airway remodeling" (1-5). Thus, the spectrum of findings in this disorder is thought to include increased numbers of mucus-secreting goblet cells in the airway epithelium, associated with excessive production of mucus, and increased deposition of collagen in the lung as well as airway hyperresponsiveness (AHR) to immunologically nonspecific agonists of bronchoconstriction and chronic inflammation of the airway mucosa, with cellular infiltrates of lymphocytes, eosinophils, and other inflammatory leukocytes (1-8).

In many patients, asthma has an allergic or atopic component, characterized by allergic sensitivity to environmental allergens and increased serum levels of antigen-specific and total $\operatorname{IgE}$ antibodies (1-3). Accordingly, attempts to understand the pathophysiology of asthma often focus on the effector cells of allergic inflammation, including the mast cell (MC). MCs are derivatives of hematopoietic progenitors that differentiate and mature locally in most tissues, especially those that are exposed to the external environment, such as the airways (9-11). Moreover, some studies have reported that MCs are present in increased numbers in the airways of patients with asthma $(8,12,13)$.

While the mechanisms responsible for the increased numbers of MCs in the airways of some asthmatic patients have not been

Nonstandard abbreviations used: AHR, airway hyperresponsiveness; BAL, bronchoalveolar lavage; BMCMC, bone marrow-derived cultured mast cell; BMCMCs $\rightarrow K i t^{W / W-v}$, BMCMC-engrafted $K i t^{W / W-v}$ mice; $\mathrm{C}_{\text {dyn }}$, dynamic compliance; $M C$, mast cell; Penh, enhanced respiratory pause; $\mathrm{R}_{\mathrm{L}}$, lung resistance.

Conflict of interest: The authors have declared that no conflict of interest exists. Citation for this article: J. Clin. Invest. 116:1633-1641 (2006). doi:10.1172/JCI25702. defined, there is no doubt that MCs have the potential to influence multiple aspects of the pathology and pathophysiology of asthma. For example, MCs express the high affinity receptor for $\operatorname{IgE}$ (i.e., FceRI) on their surface and therefore can bind IgE (14-16). Upon exposure to di- or multivalent antigen recognized by FceRI-bound IgE, these FceRI undergo aggregation, initiating a complex process of signal transduction that culminates in the secretion of a broad spectrum of proinflammatory mediators, cytokines, and chemokines $(11,14-16)$. In the mouse, the $F c R \gamma$ chain $(F c R \gamma)$ is shared by FceRI and Fc $\gamma$ RIII (17), and MCs can be activated to release mediators via Ag-, IgG1-, and FcyRIII-dependent mechanisms (17-22) as well as by Ag-, IgE-, and FceRI-dependent mechanisms (14-16).

These MC-derived products can have diverse effects in the airways, including those that might, at least in part, contribute to multiple features of this disorder $(1,8,13,23,24)$. Thus, individual MC mediators, cytokines, or chemokines can promote AHR and chronic allergic inflammation, goblet cell hyperplasia, enhanced mucin gene expression and mucus secretion, and collagen deposition $(1,8,13,23,24)$. Moreover, patients with active asthma or asthma patients challenged via the airways with allergens to which they have sensitivities exhibit evidence of MC activation, such as increased levels of MC-derived products in bronchoalveolar lavage (BAL) fluid $(13,24)$. Finally, histological signs of airway MC degranulation in vivo can be identified in biopsy specimens derived from asthmatic patients $(6,13,24)$.

Yet it is not at all clear to what extent MCs and IgE-dependent MC activation actually are important for the long-term pathology of asthma. First, a number of other inflammatory cells, including $\mathrm{T}$ lymphocytes, macrophages, eosinophils, basophils, and neutrophils, have also been implicated as potential effector cells in asthma $(6,8,25-28)$. However, in humans, it can be difficult to ascertain the individual contributions of each of these potential effector cells to the pathology of the disorder. Second, while attempts to treat asthma by reducing levels of IgE with the humanized anti-IgE antibody omalizumab have produced clinical benefit in some patients, the magnitude of such benefit often is 

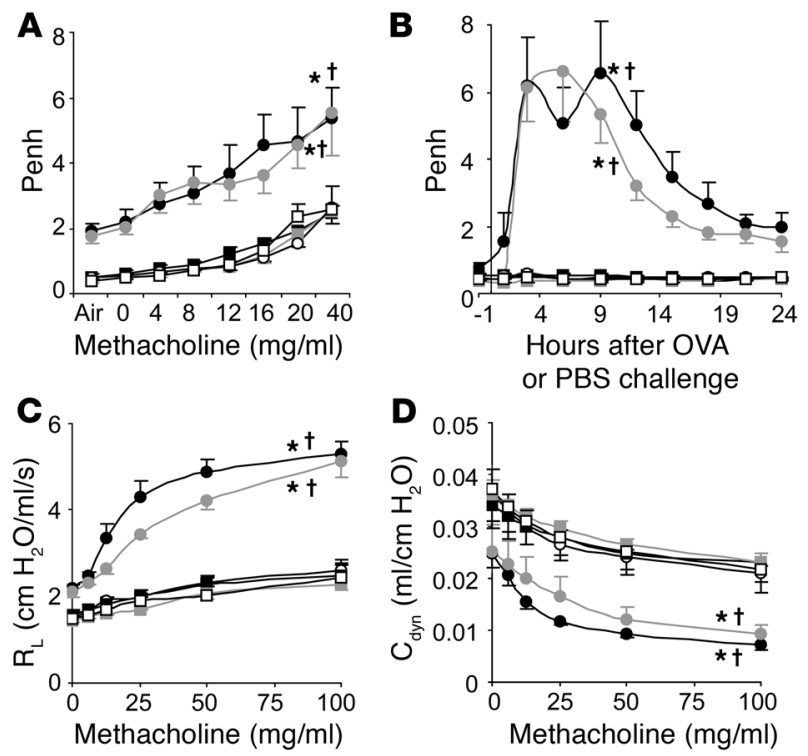

limited $(29,30)$. The extent to which the relatively modest clinical results obtained with omalizumab reflect an inability to reduce IgE levels to sufficiently low levels, as opposed to the presence of mechanisms of disease pathogenesis that operate independently of $\operatorname{IgE}$, is not clear.

Studies of asthma models in mice can exploit the power of genetic approaches in analyzing how the presence or absence of potential effector elements can influence the expression of the various features of the models $(23,31)$. Such work has implicated MCs in the expression of certain features that develop in relatively shortterm models of asthma, including AHR and eosinophil-containing inflammatory infiltrates in the lung (32-34). However, in other short-term models of asthma, which typically involve sensitization with antigen administered together with an adjuvant such as aluminum hydroxide, AHR and eosinophil infiltration can be elicited in animals that genetically lack MCs $(23,25,33,35)$.

Even though humans with allergic asthma are typically exposed to allergens repeatedly over long periods of time, only a few studies of mice have investigated protocols of allergen challenge that attempt to mimic this pattern of exposure (36-38). Moreover, all of the latter mouse studies used sensitization protocols that included artificial adjuvants. We developed a long-term protocol for i.n. antigen challenge of mice that had been sensitized without artificial adjuvant and that results in the development of many of the features of chronic asthma. We then used that model to investigate the extent to which MCs and MC activation by FcR $\gamma$ dependent mechanisms are required for optimal development of multiple features of chronic asthma in mice.

\section{Results}

Airway responses to antigen or methacholine are largely $M C$ dependent. In our chronic asthma model, OVA-sensitized wild-type $\left(\mathrm{Kit}^{+/+}\right)$mice exhibited increased enhanced respiratory pause (Penh) responses to aerosolized methacholine administered 24 hours after the eighth OVA challenge compared with responses in PBS-treated WBB6F ${ }_{1}-\mathrm{Kit}^{+/+}$mice or OVA- or PBS-treated MC-deficient $\mathrm{WBB} \mathrm{F}_{1^{-}}$ $K i t^{W / W-v}$ mice (Figure 1A). However, $\mathrm{WBB}^{\mathrm{W}} \mathrm{F}_{1}-\mathrm{Kit}^{\mathrm{W} / \mathrm{W}-v}$ mice that had been selectively engrafted with $\mathrm{WBB} \mathrm{F}_{1}-\mathrm{Kit}^{+/+}$bone marrow-

\section{Figure 1}

Airway responses following i.n. OVA challenge in a mouse model of chronic asthma. (A) Penh responses to aerosolized methacholine 24 hours after the eighth OVA or PBS challenge. (B) Penh measured 1 hour before and 1, 3, 6, 9, 12, 15, 18, 21, and 24 hours after the ninth OVA or PBS challenge. (C) Changes in $R_{L}$ and (D) lung $C_{d y n}$ after aerosolized methacholine administered 24 hours after the ninth OVA or PBS challenge. Data are from OVA-sensitized/challenged $\mathrm{WBB} \mathrm{F}_{1}$ $\mathrm{Kit}^{+/+}$(filled circles), WBB6F $\mathrm{F}_{1}-\mathrm{Kit}^{\mathrm{W} / \mathrm{W}-\mathrm{v}}$ (open circles), and WBB6F $\mathrm{F}_{1}-\mathrm{Kit}^{+/+}$

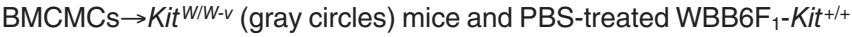
(filled squares), $\mathrm{WBB} \mathrm{F}_{1}-K i t^{W / W-v}$ (open squares), and $\mathrm{WBB} \mathrm{F}_{1}-\mathrm{Kit}^{+/+}$ BMCMCs $\rightarrow K i t^{W / W-v}$ (gray squares) mice. ${ }^{*} P<0.05$ versus corresponding PBS-treated controls; ${ }^{\dagger} P<0.05$ versus OVA-sensitized/challenged Kit ${ }^{W / W-v}$ group. $n=8$ per group $(\mathbf{A}$ and $\mathbf{B}) ; n=4 \operatorname{per} \operatorname{group}(\mathbf{C}$ and $\mathbf{D})$.

derived cultured MCs (BMCMCs) $\left(\mathrm{Kit}^{+/+} \mathrm{BMCMCs} \rightarrow \mathrm{Kit}{ }^{W / W-v}\right.$ mice) exhibited responses that were statistically indistinguishable from those in $\mathrm{Kit}^{+/+}$mice (Figure 1A). Very similar results were obtained when such experiments were repeated using C57BL/6-Kit ${ }^{+/+}$, $\mathrm{C} 57 \mathrm{BL} / 6-\mathrm{Kit}^{\mathrm{W}-\mathrm{s} h / \mathrm{W}-\mathrm{s} h}$, and C57BL/6-Kit ${ }^{+/+} \mathrm{BMCMCs} \rightarrow \mathrm{Kit}^{\mathrm{W}-\mathrm{s} h / \mathrm{W}-\mathrm{s} h}$ mice (Supplemental Figure 1A; supplemental material available online with this article; doi:10.1172/JCI25702DS1).

Thus, in this model, airway responses to methacholine appeared to be largely or entirely $\mathrm{MC}$-dependent in either $\mathrm{WB} \times \mathrm{C} 57 \mathrm{BL} / 6 \mathrm{~F}_{1}$ (i.e., $\mathrm{WBB}_{6} \mathrm{~F}_{1}$ ) or $\mathrm{C} 57 \mathrm{BL} / 6$ mice. Indeed, the role of MCs in the enhancement of Penh responses to methacholine in this chronic model appeared to be even greater than that which we reported in a more acute model of asthma, which also was elicited in mice that had been sensitized to OVA in the absence of artificial adjuvant (33).

We also measured airway responses to antigen or PBS. Individual OVA-sensitized $\mathrm{Kit}^{+/+}$or $\mathrm{Kit}^{+/+} \mathrm{BMCMCs} \rightarrow \mathrm{Kit}^{\mathrm{W} / \mathrm{W}-\mathrm{v}}$ mice exhibited a biphasic response to the ninth OVA challenge, with peaks of responsiveness at approximately 3 or 6 hours and at approximately 9 or 12 hours; the responses were substantially reduced by 24 hours after OVA challenge (Supplemental Figure 2). When data from individual mice were pooled, the biphasic response to OVA was still evident in OVA-sensitized $\mathrm{Kit}^{+/+}$mice but not in OVA-sensitized $\mathrm{Kit}^{+/+} \mathrm{BMCMCs} \rightarrow \mathrm{Kit}^{\mathrm{W} / \mathrm{W}-\mathrm{v}}$ mice (Figure 1B). However, peak airway responses in these 2 groups were quite similar in magnitude. In contrast, there were no detectable responses to OVA in OVA-sensitized Kit ${ }^{W / W-v}$ mice, nor did any group of PBS-treated mice exhibit a response to PBS challenge (Figure $1 \mathrm{~B}$ ). Very similar results were obtained when the same experiments were performed in C57BL/6$\mathrm{Kit}^{+/+}$, C57BL/6-Kit W-sh/W-sh, and C57BL/6-Kit ${ }^{+/+} \mathrm{BMCMCs} \rightarrow \mathrm{Kit}{ }^{\mathrm{W}-\mathrm{s} /} / \mathrm{W}-\mathrm{s} h$ mice (Supplemental Figure 1B).

Thus, airway responses induced by OVA challenge in OVA-sensitized $K i t^{W / W-v}$ or $K i t^{W-s h / W-s h}$ mice, like Penh responses to methacholine after OVA challenge in such mice, were largely or entirely MC dependent.

To assess specifically airway responses distal to the trachea, we also performed invasive measurements of lung resistance $\left(\mathrm{R}_{\mathrm{L}}\right)$ and dynamic compliance $\left(C_{\text {dyn }}\right)$ in mice treated with aerosolized methacholine 24 hours after the ninth challenge with OVA or PBS. OVAsensitized $\mathrm{Kit}^{+/+}$or $\mathrm{Kit}^{+/+} \mathrm{BMCMCs} \rightarrow \mathrm{Kit}{ }^{\mathrm{W} / \mathrm{W}-v}$ mice exhibited similar levels of AHR after OVA challenge whereas the OVA-sensitized MC-deficient $K i t^{W / W-v}$ mice showed responses that were statistically indistinguishable from those of the PBS-treated control groups (Figure 1, C and D). Thus, our findings using invasive measurements of lung function to assess AHR in anesthetized, tracheostomized mice are basically in accord with those we obtained by using Penh to assess airway responses in conscious mice. 


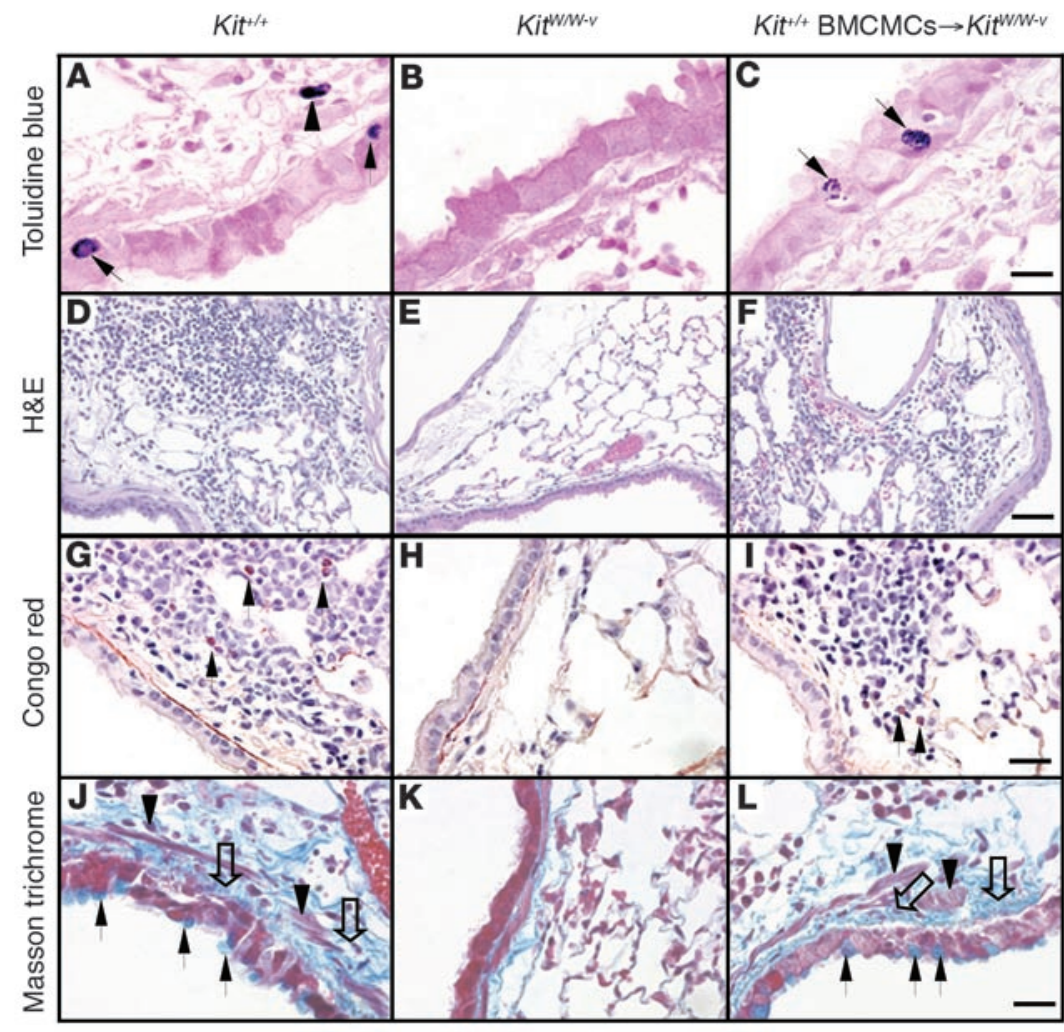

\section{Figure 2}

Histology of lungs of OVA-sensitized/challenged mice 24 hours after the ninth OVA challenge. (A-C) Toluidine blue stain demonstrating MCs (MCs within the epithelium are indicated by arrows in $\mathbf{A}$ and $\mathbf{C}$; a submucosal $M C$ is indicated by an arrowhead in A). Scale bar: $10 \mu \mathrm{m}$. (D-F) H\&E staining showing perivascular and peribronchial infiltrates of inflammatory cells. Scale bar: $50 \mu \mathrm{m}$. (G-I) Congo red stain showing eosinophils (some indicated by arrows) and lymphocytes in the inflammatory infiltrates. Scale bar: $20 \mu \mathrm{m}$. (J-L) Masson trichrome stain showing hyperplasia of mucin-secreting goblet cells and subepithelial fibrosis. Black arrows indicate goblet cells, open arrows indicate collagen (stained blue), and arrowheads indicate airway smooth muscle. Scale bar: $15 \mu \mathrm{m}$.

receptor (11). However, the lungs of OVA-treated $K i t^{W / W-v}$ mice (Figures $2 \mathrm{~B}$ and $3 \mathrm{~A}$ ) or Kit ${ }^{W-s h / W-s h}$ mice (Supplemental Figure 4A) remained completely devoid of MCs. In contrast, lung MC numbers in OVA- or PBS-treated $\mathrm{Kit}^{+/+} \mathrm{BMCMCs} \rightarrow \mathrm{Kit}^{\mathrm{W} / \mathrm{W}-\mathrm{v}}$ mice were statistically indistinguishable from those in $\mathrm{Kit}^{+/+}$mice (Figures $2 \mathrm{C}$ and $3 \mathrm{~A}$ ); similar findings were observed in $\mathrm{Kit}^{+/+} \mathrm{BMCMCs} \rightarrow$ $\mathrm{Kit}^{W-s h / W-s h}$ mice (Supplemental Figure 4A).

In OVA-sensitized/challenged $\mathrm{WBB} \mathrm{F}_{1}-\mathrm{Kit}^{+/+}$ mice, the ninth OVA challenge resulted in a rapid rise in the levels of histamine detectable in the

Antibody responses in this model are MC independent. MCs can be activated by antigen to secrete mediators by both IgE/FceRI- and IgG/Fc $\gamma$ RIII-dependent mechanisms (14-22). Such secreted products include cytokines that can regulate the production of IgE and other antibodies $(23,39,40)$. MCs can also express other functions that have the potential to influence the development of adaptive immune responses $(23,39,40)$. Accordingly, it has been proposed that MCs might function in part to enhance levels of antibody production during some acquired immune responses $(23,39,40)$.

We found that OVA sensitization resulted in the development of significant antigen-specific IgE and IgG1 responses, but the levels of these antibodies measured at the end of our experiments in groups of OVA-sensitized $\mathrm{Kit}^{+/+}, \mathrm{Kit}^{\mathrm{W} / \mathrm{W}-\mathrm{v}}$, or $\mathrm{Kit}^{+/+} \mathrm{BMCMCs} \rightarrow$ $K i t^{W / W-v}$ mice were statistically indistinguishable (Supplemental Figure 3). Thus, the differences in airway responses to OVA or in the AHR to methacholine among OVA-sensitized $\mathrm{Kit}^{+/+}, \mathrm{Kit}^{\mathrm{W} / \mathrm{W}-v}$, or $\mathrm{Kit}^{+/+}$BMCMCs $\rightarrow K i t^{W / W-v}$ mice cannot be explained by differences in levels of OVA-specific IgE or IgG1 antibodies.

This asthma model is associated with increased numbers of MCs and MCdependent lung inflammation. OVA treatment resulted in significant increases in the numbers of MCs in the lungs of the $\mathrm{WBB}_{6} \mathrm{~F}_{1}-\mathrm{Kit}^{+/+}$ mice, including the appearance of intraepithelial MCs (Figures $2 \mathrm{~A}$ and 3A); similar findings were observed in the C57BL/6-Kit ${ }^{+/+}$mice (Supplemental Figure 4A and data not shown). These findings have also been reported in some patients with asthma (13). OVA treatment also induced other features of allergic inflammation, such as prominent infiltrates of leukocytes, including lymphocytes and eosinophils (Figures 2, D and G, and 3, B and D); again, similar findings were observed in C57BL/6-Kit ${ }^{+/+}$mice (Supplemental Figure 4, B and D).

In certain settings, $K i t^{W / W-v}$ mice can develop MC populations by mechanisms that do not require normal signaling via the c-Kit serum, with levels remaining significantly elevated over baseline (i.e., pre-OVA challenge) values even 24 hours after OVA challenge (Supplemental Figure 5 and Figure 3C). In OVA-sensitized/challenged mice, serum histamine measured 24 hours after the last OVA challenge was not only significantly elevated in $\mathrm{Kit}^{+/+}$mice, but also, albeit to a lesser extent, in $\mathrm{Kit}^{+/+} \mathrm{BMCMCs} \rightarrow \mathrm{Kit}{ }^{\mathrm{W} / \mathrm{W}-v}$ mice; in contrast, only very low and statistically indistinguishable levels of serum histamine were detected in OVA- or PBS-treated $\mathrm{Kit}^{\mathrm{W} / \mathrm{W}-\mathrm{v}}$ mice (Figure 3C); similar findings were observed in C57BL/6$\mathrm{Kit}^{+/+}$, C57BL/6-Kit W-sh/W-sh, and C57BL/6-Kit ${ }^{+/+}$BMCMCs $\rightarrow$ Kit ${ }^{W-s h / W-s h}$ mice (Supplemental Figure 4C). The corresponding values (serum histamine 24 hours after challenge) for OVAsensitized, PBS-challenged $\mathrm{WBB} \mathrm{F}_{1}-\mathrm{Kit}^{+/+}$, WBB $6 \mathrm{~F}_{1}-\mathrm{Kit}^{\mathrm{W} / \mathrm{W}-\mathrm{v}}$, or $\mathrm{WBB} \mathrm{F}_{1}-\mathrm{Kit}^{+/+} \mathrm{BMCMCs} \rightarrow K i t^{W / W-v}$ mice were $31.4 \pm 4.2,6.0 \pm 1.0$, and $28.7 \pm 4.6 \mathrm{nM}$, respectively. In naive $\mathrm{WBB} 6 \mathrm{~F}_{1}-\mathrm{Kit}^{+/+}, \mathrm{WBB} \mathrm{F}_{1^{-}}$ $K i t^{W / W-v}$, or $\mathrm{WBB}^{\mathrm{F}} \mathrm{F}_{1}-\mathrm{Kit}^{+/+} \mathrm{BMCMCs} \rightarrow K i t^{W / W-v}$ mice, serum histamine levels were $25.9 \pm 5.1,5.1 \pm 1.2$, and $23.6 \pm 3.4 \mathrm{nM}$, respectively. These results indicate that, in this setting, serum histamine is derived solely or largely from MCs and/or is derived from other cellular sources in an MC-dependent manner.

$\mathrm{Kit}^{+/+}$and $\mathrm{Kit}^{+/+} \mathrm{BMCMCs} \rightarrow \mathrm{Kit}{ }^{\mathrm{W} / \mathrm{W}-v}$ mice were also very similar in measurements of the inflammation associated with responses to OVA sensitization and challenge, with markedly increased numbers of inflammatory cells in the lungs versus only minimal responses in $\mathrm{Kit}^{\mathrm{W} / \mathrm{W}-v}$ mice (Figures 2, D-I, and 3, B and D). OVA-treated $\mathrm{Kit}^{+/+}$or $\mathrm{Kit}^{+/+} \mathrm{BMCMCs} \rightarrow K i t^{W / W-v}$ mice also exhibited significant elevations in BAL fluid monocytes, macrophages, neutrophils, eosinophils, and lymphocytes (Figure 3D). While there were some differences in the number of individual types of leukocytes in the BAL fluid of antigenchallenged $\mathrm{Kit}^{+/+}$versus $\mathrm{Kit}^{+/+} \mathrm{BMCMCs} \rightarrow \mathrm{Kit}^{\mathrm{W} / \mathrm{W}-\mathrm{v}}$ mice, taken together, the data in Figures 2, D-I, and 3, B and D, demonstrate that MCs 

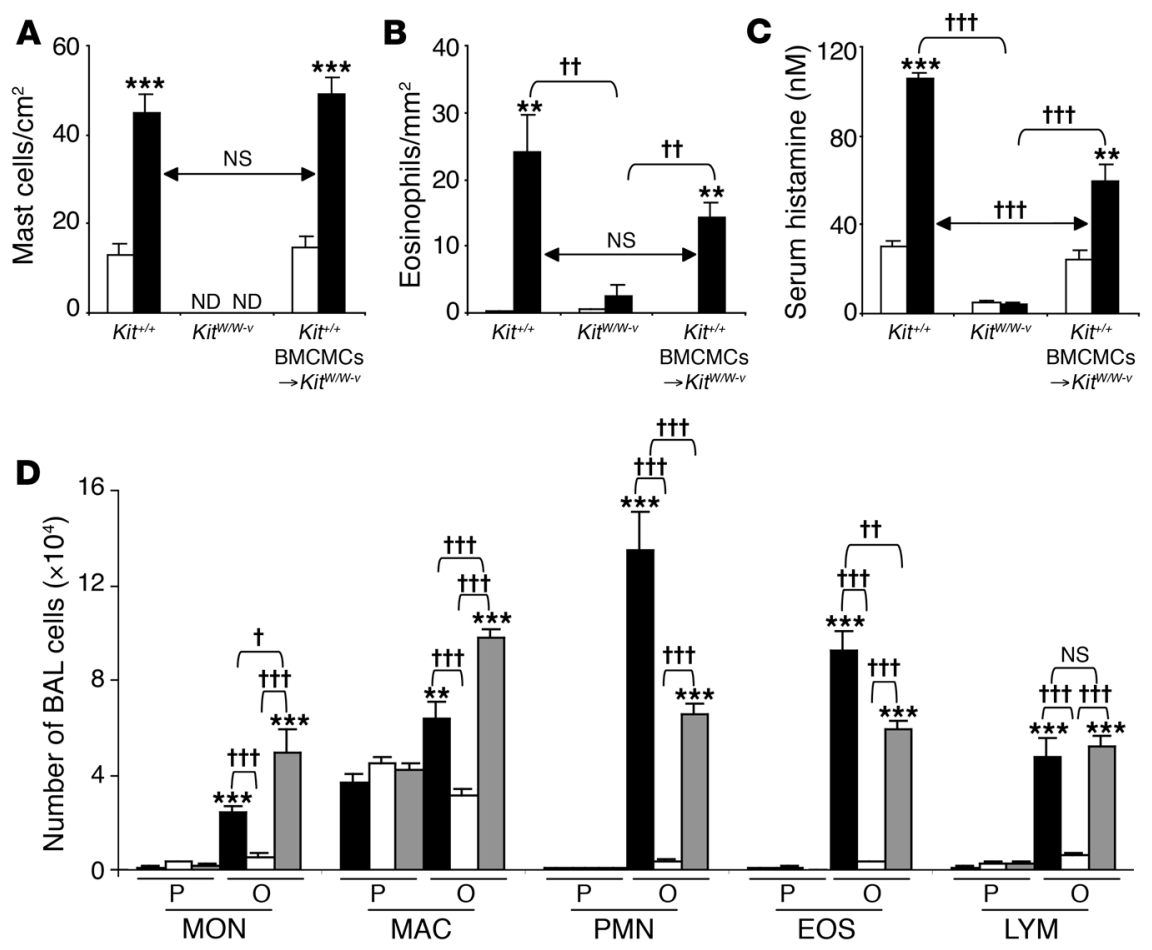

Figure 3

Features of allergic inflammation in this chronic asthma model 24 hours after the ninth OVA or PBS challenge. (A and B) Numbers of lung MCs $(\mathbf{A})$ and eosinophils (B). (C) Serum histamine concentration. (A-C) White bars, PBS-treated group; black bars: OVA-sensitized/challenged group. ${ }^{* \star} P<0.01$ or ${ }^{* *} P<0.001$ versus corresponding PBS controls $(n=6)$; ${ }^{t+} P<0.01$ or ${ }^{+t+} P<0.001$ versus group indicated ( $n=6$ per group). ND, not detected. (D) Numbers of leukocytes in $\mathrm{BAL}$ fluid from the right lungs of $\mathrm{WBB} \mathrm{F}_{1-}$ $\mathrm{Kit}^{+/+}$(black bars), WBB6 $\mathrm{F}_{1}-K_{i t^{W / W-v}}$ (white bars), and $\mathrm{Kit}^{+/+} \mathrm{BMCMC} \rightarrow K i t^{\mathrm{W} / \mathrm{W}-\mathrm{v}}$ (gray bars) mice following OVA sensitization/challenge $(\mathrm{O})$ or PBS treatment $(\mathrm{P}) .{ }^{* *} P<0.01$ or ${ }^{* * *} P<0.001$ versus corresponding PBS controls ( $n=8$ per group); ${ }^{\dagger} P<0.05,{ }^{\dagger \dagger} P<0.01$, or ${ }^{t+t} P<0.001$ versus group indicated $(n=8$ per group). MON, monocytes; MAC, macrophages; PMN, neutrophils; EOS, eosinophils; LYM, lymphocytes. are largely responsible for the antigen-induced leukocyte recruitment and chronic inflammation in this model. The same conclusion was supported when the same experiments were repeated using C57BL/6$\mathrm{Kit}^{+/+}, \mathrm{C} 57 \mathrm{BL} / 6-\mathrm{Kit}^{W-s h / W-s h}$, and C57BL/6-Kit ${ }^{+/+} \mathrm{BMCMCs} \rightarrow \mathrm{Kit} t^{W-s h / W-s h}$ mice (Supplemental Figure 4, B and D).

Activation of MCs via IgE or, in the mouse, IgG1 antibodies requires signaling through the $\mathrm{FcR} \gamma$ chain $(\mathrm{FcR} \gamma)$ that is shared by FceRI and FcyRIII $(14,17)$. We found that levels of FcR $\gamma$ mRNA in lungs obtained 24 hours after the last challenge with OVA or PBS were highly upregulated in OVA-treated $\mathrm{Kit}^{+/+}$or $\mathrm{Kit}^{+/+} \mathrm{BMCMCs} \rightarrow$ $\mathrm{Kit}^{W / W-v}$ mice but not in MC-deficient Kit ${ }^{W / W-v}$ mice (Figure 4A); similar results were obtained in C57BL/6-Kit ${ }^{+/}$, C57BL/6-Kit ${ }^{W-s h / W-s h}$, and $\mathrm{C} 57 \mathrm{BL} / 6-\mathrm{Kit}^{+/+} \mathrm{BMCMCs} \rightarrow \mathrm{Kit}^{\mathrm{W}-\mathrm{s} b / \mathrm{W}-\mathrm{s} h}$ mice (Supplemental Figure 6). Although $\mathrm{FcR} \gamma$ is not restricted to MCs (41), these results are in accord with our findings that levels of tissue MCs and other hematopoietic cells are much more markedly increased in the lungs of OVA-challenged as opposed to PBS-challenged wild-type, $\mathrm{Kit}^{+/+} \mathrm{BMCMCs} \rightarrow \mathrm{Kit}^{\mathrm{W} / \mathrm{W}-\mathrm{v}}$, or $\mathrm{Kit}^{+/+} \mathrm{BMCMCs} \rightarrow \mathrm{Kit}^{\mathrm{W}-\mathrm{s} b / \mathrm{W}-\mathrm{s} b}$ mice than in OVA-challenged MC-deficient $K i t^{W / W-v}$ or $\mathrm{Kit}^{\mathrm{W}-\mathrm{s} h / \mathrm{W}-\mathrm{s} h}$ mice (Figures 2, A-I, and 3, A, B, and D; Supplemental Figure 4, A, B, and $D)$. We also quantified levels of a transcript which is thought to

be restricted to T cells, i.e., T cell-associated GTPase (42), and found that levels of this mRNA were also highly upregulated in the lungs of OVA-treated $\mathrm{Kit}^{+/+}$or $\mathrm{Kit}^{+/+} \mathrm{BMCMCs} \rightarrow \mathrm{Kit}{ }^{\mathrm{W} / \mathrm{W}-v}$ mice but not in MC-deficient and $K i t^{W / W-v}$ mice (Figure 4B).

Taken together, these quantitative RT-PCR results are consistent with our histological findings, which showed that OVA treatment was associated with increased numbers of MCs (Figures 2, A and C, and 3A; Supplemental Figure 4A) and striking lung infiltrates of lymphocytes, as well as of other leukocytes (Figure 2, D, F, G, and I, and data not shown).

MC-dependent enhancement of airway goblet cell hyperplasia, mucin gene expression, and collagen deposition. Quantitative RT-PCR analysis demonstrated a highly MC-dependent upregulation of expression of genes encoding mucins $5 \mathrm{AC}$ and $5 \mathrm{~B}$, which are the major components of mucus secreted by goblet cells and submucosal glands, respectively $(7,43$ ) (Figure 5, A and B; Supplemental Figure 7, A and $\mathrm{B})$. These findings are consistent with our histological observations, which revealed that the striking increases in numbers of mucus-secreting goblet cells in the airway epithelium of OVAtreated mice were largely or fully MC-dependent (Figures 2, J-L, and 5C; Supplemental Figure 7C).

A

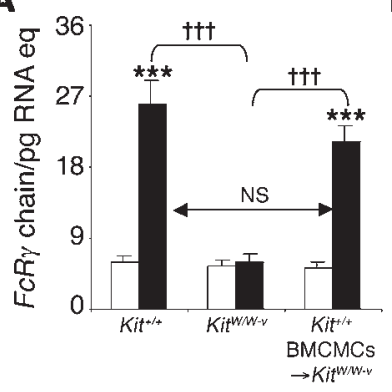

B

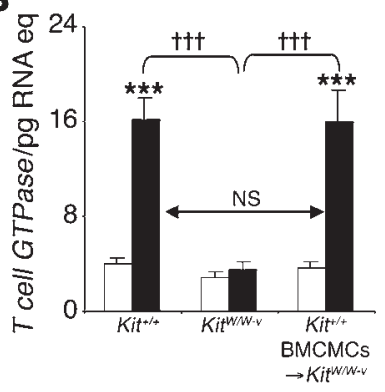

\section{Figure 4}

Lung mRNA levels of genes encoding (A) FCR chain and (B) $T$ cellspecific GTPase 24 hours after the ninth OVA or PBS challenge. White bars, PBS-treated group; black bars, OVA-sensitized/ challenged group. ${ }^{* * \star} P<0.001$ versus corresponding PBS controls ( $n=6$ per group); ${ }_{\mathrm{t}+} P<0.001$ versus group indicated ( $n=6$ per group). Eq, equivalents. 
A
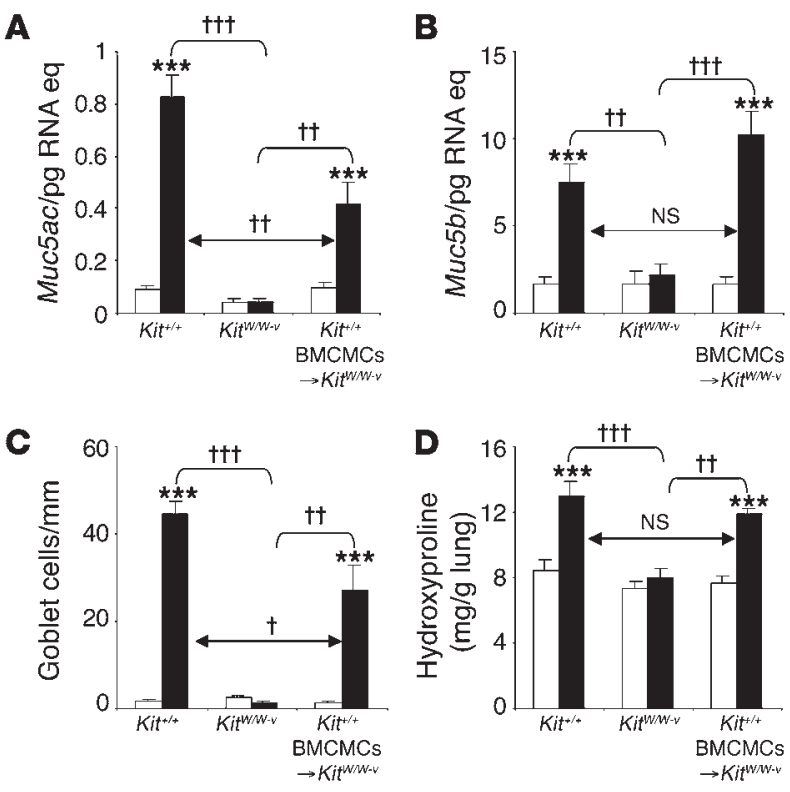

Masson trichrome staining revealed that OVA treatment resulted in enhanced deposition of collagen in the airways of $\mathrm{Kit}^{+/+}$or $\mathrm{Kit}^{+/+}$ BMCMCs $\rightarrow K i t^{W / W-v}$ mice but had little or no such effect in the airways of $K i t^{W / W-v}$ mice (Figure 2, J-L); similar results were observed in $\mathrm{C} 57 \mathrm{BL} / 6-\mathrm{Kit}^{+/+}, \mathrm{C} 57 \mathrm{BL} / 6-\mathrm{Kit}^{\mathrm{W}-\mathrm{sh} / \mathrm{W}-\mathrm{sh}}$, and C57BL/6-Kit ${ }^{+/+} \mathrm{BMCMCs} \rightarrow$ $K i t^{W-s h / W-s h}$ mice (data not shown). Much of this enhanced collagen deposition was localized in the airways immediately below the airway epithelium, a location that also exhibited what appeared to be an increased amount of airway smooth muscle (Figure 2, J and L). Quantification of lung hydroxyproline in $\mathrm{WBB} \mathrm{F}_{1}$ mice confirmed that the OVA-induced increase in lung collagen in this model was predominantly MC-dependent (Figure 5D).

$M C$ expression of $F C R \gamma$ is required for optimal expression of enhanced airway responses, numbers of airway MCs, airway inflammation, and mucin gene expression. MCs can be activated to release mediators in response to ligand-dependent engagement of multiple distinct cell surface receptors and signaling pathways (10, 11, 39). However, antigen-dependent activation of MCs via either $\operatorname{IgE} / \mathrm{FccR}_{\mathrm{RI}}$ or IgG1/Fc $\gamma$ RIII requires signaling mediated by the $\gamma$ chain $(\mathrm{FcR} \gamma)$ common to both of these receptors $(14,17)$. To examine the extent to which FceRI/FcyRIII-mediated MC activation is required for expression of our chronic asthma model, we compared the expression of various features of our model in $K i t^{W / W-v}$ or $K i t^{W-s h / W-s h}$ mice that had been engrafted with C57BL/6$F c R \gamma^{-/-}$versus C57BL/6-FcR $\gamma^{+/+}$BMCMCs.

$\mathrm{MC}$ expression of FcR $\gamma$ in BMCMCs $\rightarrow K i t^{W / W-v}$ mice had no detectable effects on the levels of total or antigen-specific IgE or IgG1 antibodies (Supplemental Figure 8). However, OVA treatment induced little or no enhancement of Penh responses to methacholine in $\mathrm{FcR}^{-/-} \mathrm{BMCMCs} \rightarrow \mathrm{Kit}^{\mathrm{W} / \mathrm{W}-v}$ mice, but substantial enhancement of the responses was observed in $F c R \gamma^{+/+} \mathrm{BMCMC} \rightarrow$ $K i t^{W / W-v}$ mice (Figure 6A). Similarly, OVA challenge of OVA-sensitized mice induced a much stronger airway response in $\mathrm{FcR \gamma}^{+/+}$ $\mathrm{BMCMC} \rightarrow K i t^{W / W-v}$ mice than in $F c R \gamma^{-/-}$BMCMCs $\rightarrow K i t^{W / W-v}$ mice (Figure 6B). Very similar results were obtained in $\mathrm{C} 57 \mathrm{BL} / 6-F c R \gamma^{+/+}$ versus $\mathrm{C} 57 \mathrm{BL} / 6-F c R \gamma^{-/-} \mathrm{BMCMCs} \rightarrow K_{i t}{ }^{W-s h / W-s h}$ mice (Supplemental Figure 9), except that the $F c R \gamma^{-/-}$BMCMCs $\rightarrow K i t^{W-s b / W-s h}$ mice,

\section{Figure 5}

Airway goblet cell numbers and mucin gene expression in this chronic asthma model 24 hours after the ninth OVA or PBS challenge. (A and B) Lung mRNA levels of genes encoding mucin $5 A C$ and mucin $5 B$. (C) Numbers of goblet cells along the airway epithelium. (D) Levels of lung hydroxyproline. White bars, PBS-treated group; black bars, OVAsensitized/challenged group. ${ }^{* * *} P<0.001$ versus corresponding PBS controls; ${ }^{\dagger} P<0.05$, ${ }^{\dagger+} P<0.01$, or ${ }^{+t \dagger} P<0.001$ versus group indicated. $n=6$ per group $(\mathbf{A}-\mathbf{C}) ; n=8$ per group (D).

in contrast to the $F c R \gamma^{-/}$BMCMCs $\rightarrow K i t^{W / W-v}$ mice, exhibited no detectable enhancement of Penh in response to OVA challenge (compare with Supplemental Figure 9B and Figure 6B).

In accord with these results, we found that expression of FcR $\gamma$ by adoptively transferred MCs significantly enhanced the ability of such MCs to orchestrate most of the other features of this chronic asthma model in the recipient $K i t^{W / W-v}$ mice (Figures 7 and 8; Supplemental Figures 10 and 11). Indeed, OVA-induced increases in numbers of lung MCs appeared to be entirely dependent on the expression of FcR $\gamma$ by the adoptively transferred MCs (Figure 7A and Supplemental Figure 10A). These results strongly suggest that an effect mediated through MC-FcR $\gamma$, perhaps including the ability of IgE antibodies to promote MC survival or proliferation even in the absence of known antigen (44-48), contributed to the increased numbers of MCs observed in this setting.

However, in some other features of the response that were strongly expressed in $\mathrm{FcR} \gamma^{+/+} \mathrm{BMCMCs} \rightarrow \mathrm{Kit}{ }^{\mathrm{W} / \mathrm{W}-\nu}$ or $\mathrm{FcR} \gamma^{+/+} \mathrm{BMCMCs} \rightarrow$ $K i t^{W-s h / W-s h}$ mice, OVA treatment also induced significant, albeit relatively modest, responses in the $F c R \gamma^{-/}$BMCMCs $\rightarrow K i t^{W / W-v}$ or $F c R \gamma^{-/}$BMCMCs $\rightarrow K i t^{W-s h / W-s h}$ mice. For numbers of lung eosinophils (Figure 7B and Supplemental Figure 10B), numbers of most types of leukocytes present in the BAL fluid 24 hours after OVA challenge (Figure 7D and Supplemental Figure 10D), and levels of mRNA of genes encoding mucin $5 \mathrm{AC}$ or $5 \mathrm{~B}$ (Figure $8, \mathrm{~B}$ and C; Supplemental Figure 11, B and C), FcR $\gamma$, and T cell GTPase (Supplemental Figure 12, A and B), the responses in the FcR $\gamma^{-/-}$
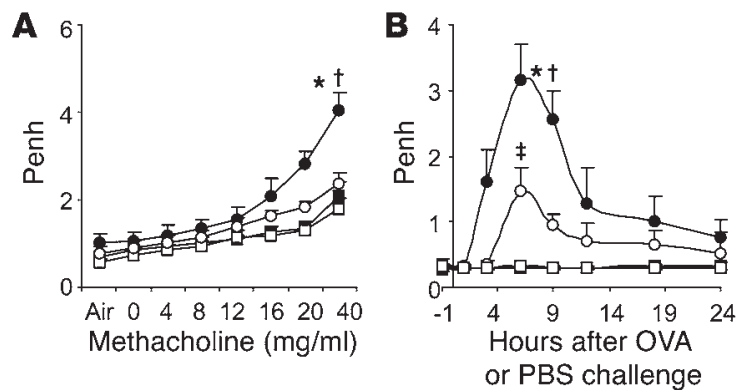

\section{Figure 6}

Penh responses following i.n. OVA antigen challenge in Kit ${ }^{W / W-v}$ mice that had been engrafted with $F_{C} R \gamma^{-/-}$versus $F c R \gamma^{+/+}$BMCMCs. (A) Responses to aerosolized methacholine 24 hours after the eighth OVA or PBS challenge. (B) Penh measured 1 hour before and 1, 3, 6, 9, 12, 18 , and 24 hours after the ninth OVA or PBS challenge. Data are from OVA-sensitized/challenged $F c R \gamma^{+/+}$BMCMCs $\rightarrow K i t^{W / W-v}$ (closed circles) and $F C R \gamma^{-1-}$ BMCMCs $\rightarrow K i t^{W / W-v}$ mice (open circles) and PBS-treated

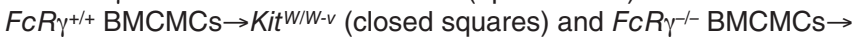
$K i t^{W} W$-v (open squares) mice. ${ }^{*} P<0.05$ versus corresponding PBS controls; ${ }^{\dagger} P<0.05$ versus OVA-sensitized/challenged $F C R^{-/-}$ BMCMCs $\rightarrow K t^{W}{ }^{W / W-v}$ mice; $\neq P<0.05$ versus values at that time point in the corresponding PBS control group; $n=6$ per group. 

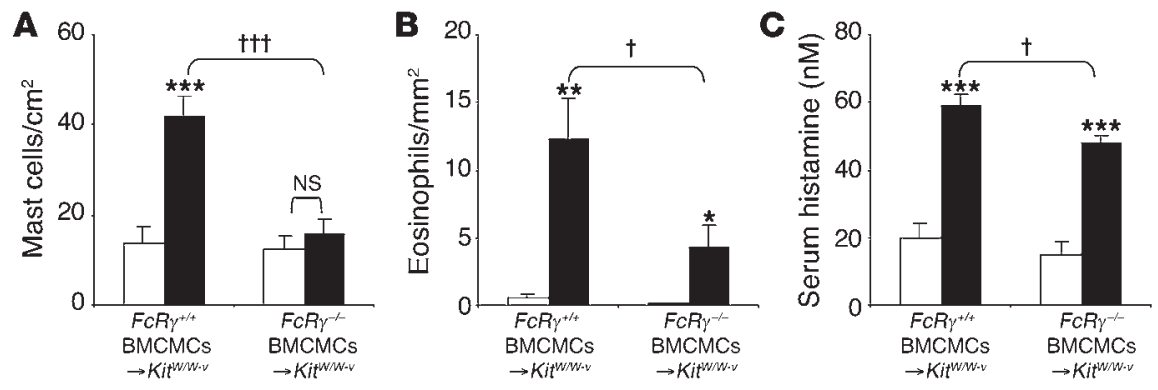

\section{Figure 7}

Features of allergic inflammation in this chronic asthma model 24 hours after the ninth OVA or PBS challenge in $\mathrm{FCR} \gamma^{-1-}$ BMCMCs $\rightarrow$ $\mathrm{Kit}^{\mathrm{W} / \mathrm{W}-\mathrm{v}}$ mice versus $\mathrm{FCR} \gamma^{+/+} \mathrm{BMCMCs} \rightarrow$ $K i t^{W / W-v}$ mice. (A and $\mathbf{B}$ ) Numbers of lung MCs (A) and eosinophils (B). (C) Serum histamine concentration. (A-C) White bars, PBS-treated group; black bars, OVA-sensitized/challenged group. (D) Numbers of leukocytes in BAL fluid from the right lungs of $\mathrm{FCR}_{\mathrm{\gamma}} \mathrm{r}^{++} \mathrm{BMCMCs} \rightarrow$ $\mathrm{Kit}^{\mathrm{W} / \mathrm{W}-\mathrm{v}}$ (black bars) and $\mathrm{FCR} \gamma^{-/-} \mathrm{BMCMCs} \rightarrow$ Kit ${ }^{W / W-v}$ (white bars) mice. ${ }^{* \star} P<0.01$ or ${ }^{* \star *} P<0.001$ versus corresponding PBS controls; ${ }^{\dagger} P<0.05,{ }^{\dagger+} P<0.01$, or ${ }^{+t+} P<0.001$ versus group indicated ( $n=6$ per group).

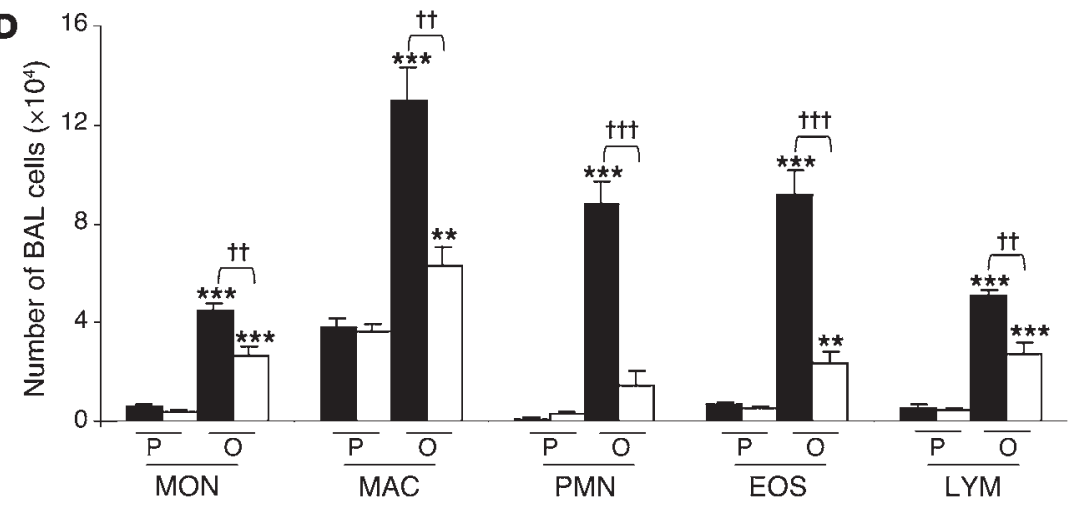

and $M u c 5 b$ mRNA in OVA-challenged mice were significantly reduced in $F c R \gamma^{-/-}$versus $F c R \gamma^{+/+}$BMCMCs $\rightarrow K i t^{W / W-v}$ mice (Figure 8, $\mathrm{B}$ and $\mathrm{C}) . \mathrm{FcR} \gamma$-independent mechanisms appeared to contribute significantly both to the increases in goblet cell numbers and to the enhanced levels of Muc5ac and $M u c 5 b$ mRNA in OVA-challenged C57BL/6 mice as well (Supplemental Figure 11).

$\mathrm{BMCMCs} \rightarrow K i t^{W / W-v}$ or $F c R \gamma^{-/-}$BMCMCs $\rightarrow K i t^{W-s h / W-s h}$ mice, although significant compared with responses in the PBS-challenged mice, were significantly lower, and in many cases at least $50 \%$ lower, than those in the OVA-challenged $F c R \gamma^{+/+}$BMCMCs $\rightarrow \mathrm{Kit}^{\mathrm{W} / \mathrm{W}-v}$ or $\mathrm{FcR} \gamma^{+/+}$ $\mathrm{BMCMCs} \rightarrow K i t^{W-s h / W-s h}$ mice. These results indicate that FcR $\gamma$-independent mechanisms of MC activation can contribute to the development of these features of this chronic asthma model but that optimal responses require $\mathrm{MC}$ expression of $\mathrm{FcR} \gamma$.

$\mathrm{FcR} \gamma$-independent mechanisms of MC activation can significantly contribute to elevations of serum histamine and increased numbers of airway goblet cells. Serum histamine levels were significantly lower in OVA-treated $\mathrm{FcR} \gamma^{-/-}$versus $\mathrm{FcR} \gamma^{+/+} \mathrm{BMCMCs} \rightarrow \mathrm{Kit}{ }^{\mathrm{W} / \mathrm{W}-v}$ mice, but the reduction was only approximately 19\% (Figure 7C). Given that virtually all of the elevation of serum histamine in this model is MC dependent (Figure 3B), the most straightforward interpretation of this finding is that in $\mathrm{WBB}_{6} \mathrm{~F}_{1}$ mice, OVA-treatment either induced MC histamine release by FcR $\gamma$-independent mechanisms or (less likely, we think) that such mechanisms permit MCs to promote histamine release from other sources. Notably, in mice on the C57BL/ 6 background, $\mathrm{FcR} \gamma$-independent mechanisms appear to be less important than FcR $\gamma$-dependent mechanisms in regulating OVA-induced histamine release (Supplemental Figure 10C).

The increased numbers of goblet cells induced in OVA-treated versus PBS-treated $F c R \gamma^{-/-}$BMCMCs $\rightarrow K i t^{W / W-v}$ mice reached levels that were nearly as high as, and were statistically indistinguishable from, the levels induced in the corresponding $F c R \gamma^{+/+}$ $\mathrm{BMCMCs} \rightarrow K i t^{W / W-v}$ mice (Figure $8 \mathrm{~A}$ ). In contrast, the enhanced levels of Muc5ac
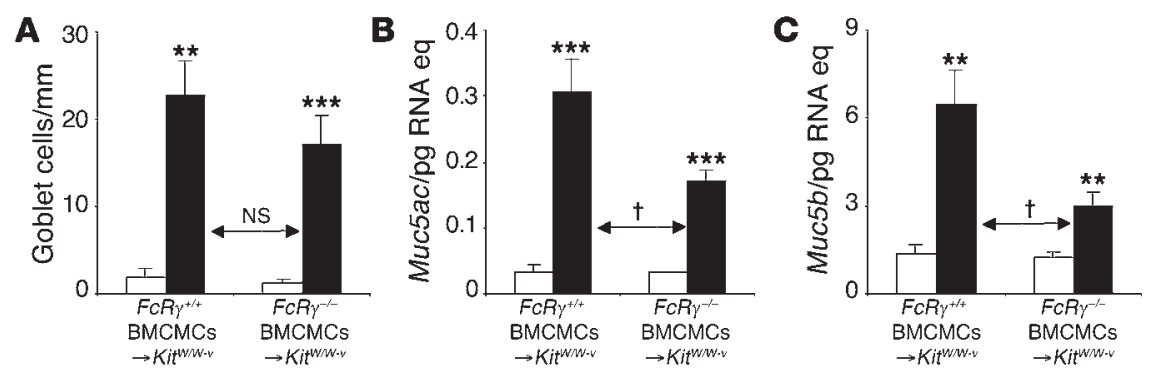

Figure 8

Airway goblet cell numbers and mucin gene expression in this chronic asthma model 24 hours after the ninth OVA or PBS challenge in FCR $\gamma^{-/-}$BMCMCs $\rightarrow K i t^{W / W-v}$ mice versus $F C R \gamma^{+/+}$ BMCMCs $\rightarrow K i t^{W / W-v}$ mice. (A) Numbers of goblet cells along the airway epithelium. (B and $\mathbf{C}$ ) Lung mRNA levels of genes encoding mucin $5 \mathrm{AC}$ and mucin $5 \mathrm{~B}$. White bars, PBS-treated group; black bars, OVA-sensitized/challenged group. ${ }^{* *} P<0.01$ or ${ }^{* *} P<0.001$ versus corresponding PBS controls; ${ }^{\dagger} P<0.05$ versus group indicated ( $n=6$ per group). 
individual features of the pathology and pathophysiology in this model require that MCs express $\mathrm{FcR} \gamma$, and MC expression of FcR $\gamma$ appears to be required for virtually all of the increase in lung MC numbers observed in OVA-treated mice (Supplemental Table 2).

Notably, using the more recently described MC-engrafted C57BL/6-Kit ${ }^{W-s h / W-s h}$ mouse model $(49,50)$, in which both the adoptively transferred $F c R \gamma^{-/-}$or $F c R \gamma^{+/+}$BMCMCs and the recipient genetically MC-deficient $K i t^{W-s h / W-s h}$ mice are all on the C57BL/6 background, we obtained results very similar to those obtained in experiments employing the transfer of $\mathrm{C} 57 \mathrm{BL} / 6-F c R \gamma^{-/-}$versus $\mathrm{C} 57 \mathrm{BL} / 6-\mathrm{FcR}^{+/+} \mathrm{BMCMCs}$ into $\mathrm{WBB} \mathrm{F}_{1}-\mathrm{Kit}^{\mathrm{W} / \mathrm{W}-\mathrm{v}}$ mice.

The simplest interpretation of these findings is that these $\mathrm{MC}$ $\mathrm{FcR} \gamma$-dependent features of the response reflect consequences of the activation of MCs by antigen and antigen-specific IgE and/ or IgG1 antibodies $(11,14,18)$. However, some features of the response, including the marked increase in lung MCs, may also (or alternatively) reflect actions of IgE on MCs that are mediated through FcR $\gamma$ but can be observed in the absence of known specific antigen $(47,48)$; these effects include the promotion of MC survival, proliferation, and cytokine production (44-48). Nevertheless, our findings clearly identify the activation of MCs via FcR $\gamma$ dependent mechanisms as a key promoter of many of the features of this chronic asthma model. Such findings support the view that IgE-dependent $\mathrm{MC}$ activation represents an attractive therapeutic target in asthma $(14,30,51)$.

However, our study also shows that certain features of this model are significantly influenced by effects of MCs that are independent of MC-FcR $\gamma$. Such antigen- and MC-dependent but MCFcR $\gamma$-independent effects contribute importantly in this model to the striking increases in the numbers of epithelial goblet cells (especially in mice on the $\mathrm{WBB}_{6} \mathrm{~F}_{1}$ background) and also contribute significantly to the elevated levels of mRNA for mucins 5AC and $5 \mathrm{~B}$ in the lungs (in both $\mathrm{WBB} \mathrm{F}_{1}$ and $\mathrm{C} 57 \mathrm{BL} / 6$ mice). These findings have interesting implications for our understanding of the factors that contribute to enhanced mucin production in human asthma. Among the $18 \mathrm{Muc}$ genes that have been identified in humans, $M u c 5 a c$ and $M u c 5 b$ gene products represent the major gel-forming mucins in airway secretion $(7,43)$. And it has been reported that increased levels of mucin $5 \mathrm{AC}$ and mucin $5 \mathrm{~B}$ can be detected in patients with asthma $(6,7)$. Increased mucin production contributes significantly to airway obstruction and AHR in asthma; accordingly, several potential therapies targeting mucus hypersecretion are currently under development $(7,52)$. Our data indicate that, at least in mice, MCs are major contributors to goblet cell hyperplasia and increased expression of Muc5ac and Muc5b that are observed in this model of chronic asthma.

$\mathrm{FcR} \gamma$-independent mechanisms of MC engagement also contribute significantly to elevations of levels of serum histamine (especially in mice on the $\mathrm{WBB} \mathrm{F}_{1}$ background), lung infiltration with eosinophils and lymphocytes, and recruitment of leukocytes to the airways in response to antigen challenge, as reflected in counts of cells in BAL fluid. Moreover, some of the entirely MC-dependent airway responsiveness to antigen challenge in $\mathrm{WBB}_{6} \mathrm{~F}_{1}$ mice (Figure $1 \mathrm{~B}$ ) and perhaps even some of the MC-dependent AHR to methacholine (Figure 1A) in this model also appear to reflect contributions by $\mathrm{MC}$-dependent but $\mathrm{MC}-\mathrm{FcR} \gamma$-independent processes (Figure 6, A and B). In contrast, in C57BL/6 mice, there was no detectable contribution of $\mathrm{MC}-\mathrm{FcR} \gamma$-independent processes to the MC-dependent enhancement of Penh responses to either methacholine or antigen (Supplemental Figure 9).
In summary, our findings in this mouse model show that MCs can represent key drivers of many important inflammatory, structural, and functional changes of the lungs that are also observed in chronic human asthma. These observations are thus in accord with the many reports implicating MCs and their products in the pathology of human asthma $(13,24)$. However, while some of the features of our chronic asthma model appear to be strongly dependent on MC expression of FcR $\gamma$, other effects are clearly antigen- and MC-dependent but also significantly MC-FcR $\gamma$-independent. Our findings show that this MC-FcR $\gamma$-independent pathway can elicit important contributions of MCs to several critical features of chronic asthma, including epithelial goblet cell hyperplasia and markedly enhanced expression of genes encoding mucins 5AC and 5B.

On the other hand, the importance of such MC-dependent but $\mathrm{MC}-\mathrm{FcR} \gamma$-independent pathways in this model may be influenced by the genetic background of the mice, in that such pathways appeared to be more important in the development of goblet cell hyperplasia and in the elevations of serum histamine after OVA challenge observed in $\mathrm{WBB}_{6} \mathrm{~F}_{1}$ as opposed to $\mathrm{C} 57 \mathrm{BL} / 6$ mice.

Adding even more complexity, a very large number of candidate mechanisms might be proposed to account for the MC-dependent but MC-FcR $\gamma$-independent pathways that appear to contribute to the development of some of the features of this model. MCs can be activated independently of FcR $\gamma$ by multiple factors that may be present in tissues affected by asthma in humans or by models of asthma in mice, including products of complement activation (C5a and C3a) as well as certain neuropeptides, neurotrophins, chemokines, products of recruited leukocytes, and other types of products that can induce or enhance MC activation $(10,39,40$, 53-55). Complicating further any analysis of the potential roles of such factors in our model are observations indicating that many (if not all) of these factors may be able to influence features of asthma independently of any effects they may have on MCs.

For example, we previously reported that $\mathrm{C} 5 \mathrm{a}$ and $\mathrm{C} 3 \mathrm{a}$ can promote contractile responses in intestinal smooth muscle independently of any contribution of MCs (56). Notably, aerosolized C5a can also induce elevations of Penh and increased numbers of BAL leukocytes independently of MCs in mice on either the

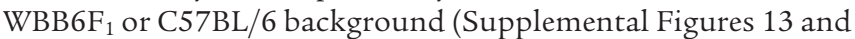
14). Accordingly, we expect that extensive work (and probably some good fortune) may be required to identify the important MC-dependent but MC-FcR $\gamma$-independent pathways that can contribute significantly to the development of some of the features of this model of chronic asthma.

The extent to which our observations can be extended to human asthma remains to be determined. However, the findings in this mouse model raise the possibility that therapies that target the IgE-dependent activation of MCs and other effector cells may not be fully effective in the treatment of chronic asthma even if it were possible fully to eliminate IgE-dependent effector cell activation by such approaches. Indeed, our data strongly suggest that MCs themselves and $\mathrm{FcR} \gamma$-independent pathways of MC activation in addition to IgE represent promising therapeutic targets in patients with chronic asthma.

\section{Methods}

Mice. Genetically MC-deficient (WB/ReJ- $\left.W^{/+} \times \mathrm{C} 57 \mathrm{BL} / 6 \mathrm{~J}-W^{v /+}\right) \mathrm{F}_{1}-K i t^{W / W-v}$ $\left(\mathrm{WBB}_{1} \mathrm{~F}_{1}-\mathrm{Kit}^{\mathrm{W} / \mathrm{W}-\mathrm{v}}\right)$ mice, congenic normal WBB6F $1-\mathrm{Kit}^{+/+}\left(\mathrm{Kit}^{+/+}\right)$mice, and C57BL/6J mice were purchased from Jackson Laboratory. C57BL/6-Kit W-sh/W-sh mice were generously provided by Peter Besmer (Molecular Biology Program, 
Memorial Sloan-Kettering Cancer Center, New York, New York, USA); these mice were then backcrossed to C57BL/6J for more than 6 generations. FcR $\gamma^{-/-}$ mice (57) on the C57BL/6 background (B6.129P2-Fcer1gtm1Rav N12) were purchased from Taconic. Age-matched female mice were used for all experiments. All animal care and experimentation reported herein were conducted in compliance with the guidelines of the NIH and with the specific approval of Institutional Animal Care and Use Committee of Stanford University.

$M C$ engraftment. Selective engraftment of MCs in MC-deficient $\mathrm{WBB} \mathrm{F}_{1}$ $K i t^{W / W-v}$ or C57BL/6-Kit ${ }^{W-s h / W-s h}$ mice was performed as described (33), with minor modifications. Bone marrow cells derived from 4-week-old female WBB6F $_{1}-\mathrm{Kit}^{+/+}, \mathrm{C} 57 \mathrm{BL} / 6 \mathrm{~J}-\mathrm{FcR} \gamma^{+/+}\left(\mathrm{FcR} \gamma^{+/+}\right)$, or C57BL/6J-FcR $\gamma^{-/-}\left(\mathrm{FcR} \gamma^{-/}\right)$ mice were cultured in WEHI-3-conditioned medium (ATCC number TIB-68), as a source of IL-3, for 4-5 weeks to generate cell populations that contained more than $95 \%$ immature MCs. Via the tail vein, $5 \times 10^{6} \mathrm{BMCMCs}$ were injected into each mouse, and the recipients (e.g., $\mathrm{WBB}_{1} \mathrm{~F}_{1}-\mathrm{Kit}^{+/+}$ $\mathrm{BMCMCs} \rightarrow K i t^{W / W-v}$ or C57BL/6-Kit ${ }^{+/+} \mathrm{BMCMCs} \rightarrow K i t^{W-s h / W-s h}$ mice) were used for experiments 18 weeks later. Engraftment of $K i t^{W / W-v}$ mice with BMCMCs did not repair their anemia (as examined by hematocrit), confirming the selectivity of the MC engraftment $(11,33)$.

Immunization and airway challenge with antigen. Mice were immunized by 3 i.p. injections of $50 \mu \mathrm{g}$ OVA (Sigma-Aldrich) in $0.1 \mathrm{ml}$ PBS on days 1, 4 , and 7. Starting on day 12, mice were challenged i.n. with $20 \mu \mathrm{g}$ OVA in $30 \mu \mathrm{l}$ PBS weekly for 9 weeks; control mice received i.p. injections and i.n. challenges with PBS on the same schedule. As shown in Supplemental Figures 15 and 16, repeated i.n. administrations of OVA also appeared to sensitize the mice to this antigen, albeit to a significantly lesser extent than seen in mice that also received i.p. injections of OVA. Accordingly, for the experiments presented herein, we compared responses in mice that had been sensitized and challenged with OVA to those in mice that had been mock sensitized and challenged with PBS.

All experiments employed OVA preparations that contained low levels of LPS (i.e., $<100$ pg of LPS was administered during the entire sequence of OVA sensitization and challenge). Eisenbarth et al. (58) showed that low levels of LPS were required for successful induction of Th2 responses upon i.n. sensitization of $\mathrm{BALB} / \mathrm{c}$ mice with OVA that lacked aluminum hydroxide but that LPS signaling via TLR4 was not required for the development of a Th2 response after i.p. sensitization with OVA and aluminum hydroxide. LPS levels (measured with a QCL-1000 kit; Cambrex) in the OVA/PBS preparations used for i.p. sensitization versus i.n. challenge in our experiments were 170 versus $225 \mathrm{pg} / \mathrm{ml}$, respectively, and therefore each i.p. versus i.n. challenge dose of OVA/PBS contained approximately 17 versus approximately 6.8 pg of LPS.

Measurement of airway reactivity to methacholine. Twenty-four hours after the eighth OVA or PBS challenge, responses to aerosolized methacholine were measured using whole-body plethysmography (Buxco) (33). Responses to antigen (OVA) or PBS were assessed by recording Penh over 10-minute time periods at intervals before and after the ninth (final) OVA or PBS challenge (in the absence of methacholine). In some studies, we also performed invasive measurements of airway reactivity in anesthetized, tracheostomized, mechanically ventilated mice (59). Aerosolized methacholine was administered in increasing concentrations $(0,6.25,12.5,25,50$, and $100 \mathrm{mg} / \mathrm{ml}$ ), with individual doses separated by 4 minutes. $\mathrm{R}_{\mathrm{L}}$ and $\mathrm{C}_{\text {dyn }}$ were continuously computed by fitting flow, volume, and pressure to an equation of motion for each aerosol challenge period, which consisted of a 2-minute aerosol exposure and a 4-minute period after exposure.
$B A L$ and histology. For BAL, mice were killed by $\mathrm{CO}_{2}$ inhalation 24 hours after the last (ninth) OVA or PBS challenge. The left lung was ligated and removed whereas the right lung lobes were lavaged once with ice-cold HBSS (BAL) then fixed (10\% formaldehyde) and paraffin-embedded. Sections of $5 \mu \mathrm{m}$ were mounted on Superfrost Plus glass slides (Fisher Scientific) and stained with H\&E, toluidine blue, Congo red, or Masson trichrome stains.

Quantitative RT-PCR. Total RNA isolated from the left lungs using TRIzOL Reagent (Invitrogen Corp.) was reverse transcribed using the High Capacity cDNA Archive Kit (Applied Biosystems) according to the manufacturer's instructions. Quantitative real-time PCR was performed using the ABI 7700 Real-Time PCR System (Applied Biosystems) with the following cycling parameters: 10 minutes at $95^{\circ} \mathrm{C}$, then 40 biphasic cycles of $15 \mathrm{sec}-$ onds at $95^{\circ} \mathrm{C}$, and 1 minute at $60^{\circ} \mathrm{C}$. Primers and probes (see Supplemental Table 1) designed using Primer Express Software version 1.1 (Applied Biosystems) were obtained from Operon Technologies. Units are expressed as copy number per pg of RNA equivalents.

Measurement of serum antibodies and histamine. Serum was collected 24 hours after the ninth OVA or PBS challenge. Total serum IgE and IgG1 concentrations were measured by ELISA (Bethyl Laboratories). OVA-specific IgE and IgG1 concentrations were measured by ELISA (60). The OVAspecific IgE standard was a generous gift from E.W. Gelfand (National Jewish Medical and Research Center, Denver, Colorado, USA). Pooled serum from 4 randomly selected OVA-sensitized/challenged $\mathrm{WBB} \mathrm{F}_{1}-\mathrm{Kit}^{+/+}$mice was used as the internal standard, which was assigned the arbitrary value of 50 experimental units/ml for OVA-specific IgG1. Serum histamine was measured using an Enzyme Immunoassay Kit (Beckman Coulter) according to the manufacturer's instructions.

Hydroxyproline assay. Tissue hydroxyproline concentration was used to measure the collagen content of the lung. Sections of the left lung 1-mm thick were dried with acetone, approximately $10 \mathrm{mg}$ of the dried samples were hydrolyzed with $0.5 \mathrm{ml} 6 \mathrm{~N} \mathrm{HCl}$ at $110^{\circ} \mathrm{C}$ overnight, and hydroxyproline concentration was determined as in ref. 61 .

Statistics. Unless otherwise specified, differences in airway response between different groups were tested for statistical significance using ANOVA. The unpaired Student's $t$ test ( 2 tailed) was used for all other analyses. $P<0.05$ was considered statistically significant. Unless otherwise specified, all data are presented as mean \pm SEM or mean + SEM.

\section{Acknowledgments}

We thank Zhen-sheng Wang and Alian Xu for technical assistance, Peter Besmer for his gift of C57BL/6-Kit ${ }^{W-s h / W-s h}$ mice, Erwin W. Gelfand for the gift of an OVA-specific IgE standard, and members of the Galli laboratory for discussions. This work was supported by United States Public Health Service grants HL67674, AI23990, and CA72074 (to S.J. Galli) and a Ruth L. Kirschstein National Research Service Award (to M. Yu).

Received for publication May 20, 2005, and accepted in revised form April 11, 2006.

Address correspondence to: Stephen J. Galli, Department of Pathology, L-235, Stanford University School of Medicine, 300 Pasteur Drive, Stanford, California 94305-5324, USA. Phone: (650) 723-7975; Fax: (650) 725-6902; E-mail: sgalli@stanford.edu.
1. Wills-Karp, M. 1999. Immunologic basis of antigen-induced airway hyperresponsiveness. Annu. Rev. Immunol. 17:255-281.

2. Busse, W.W., and Lemanske, R.F., Jr. 2001. Asthma. N. Engl.J. Med. 344:350-362.

3. Umetsu, D.T., McIntire, J.J., Akbari, O., Macaubas,

C., and DeKruyff, R.H. 2002. Asthma: an epidemic of dysregulated immunity. Nat. Immunol. 3:715-720.

4. James, A. 2005. Airway remodeling in asthma. Curr. Opin. Pulm. Med. 11:1-6.

5. Davies, D.E., Wicks, J., Powell, R.M., Puddicombe, S.M., and Holgate, S.T. 2003. Airway remodeling in asthma: new insights. J. Allergy Clin. Immunol. 111:215-225; quiz 226.
6. Carroll, N.G., Mutavdzic, S., and James, A.L. 2002. Increased mast cells and neutrophils in submucosal mucous glands and mucus plugging in patients with asthma. Thorax. 57:677-682.

7. Rogers, D.F. 2004. Airway mucus hypersecretion in asthma: an undervalued pathology? Curr. Opin. Pharmacol. 4:241-250. 
8. Marone, G., Triggiani, M., and de Paulis, A. 2005. Mast cells and basophils: friends as well as foes in bronchial asthma? Trends Immunol. 26:25-31.

9. Kitamura, Y. 1989. Heterogeneity of mast cells and phenotypic change between subpopulations. Annu. Rev. Immunol. 7:59-76.

10. Metcalfe, D.D., Baram, D., and Mekori, Y.A. 1997. Mast cells. Physiol. Rev. 77:1033-1079.

11. Galli, S.J., et al. 2005. Mast cells as "tunable" effector and immunoregulatory cells: recent advances. Annu. Rev. Immunol. 23:749-786.

12. Brightling, C.E., et al. 2002. Mast-cell infiltration of airway smooth muscle in asthma. N. Engl.J. Med. 346:1699-1705.

13. Brightling, C.E., Bradding, P., Pavord, I.D., and Wardlaw, A.J. 2003. New insights into the role of the mast cell in asthma. Clin. Exp. Allergy. 33:550-556.

14. Kinet, J.P. 1999. The high-affinity IgE receptor ( $\mathrm{Fc}$ epsilon RI): from physiology to pathology. Annu. Rev. Immunol. 17:931-972.

15. Kawakami, T., and Galli, S.J. 2002. Regulation of mast-cell and basophil function and survival by IgE. Nat. Rev. Immunol. 2:773-786.

16. Blank, U., and Rivera, J. 2004. The ins and outs of IgE-dependent mast-cell exocytosis. Trends Immunol. 25:266-273.

17. Ravetch, J.V., and Kinet, J.P. 1991. Fc receptors. Annu. Rev. Immunol. 9:457-492.

18. Latour, S., Bonnerot, C., Fridman, W.H., and Daeron, M. 1992. Induction of tumor necrosis factoralpha production by mast cells via Fc gamma R. Role of the Fc gamma RIII gamma subunit. J. Immunol. 149:2155-2162.

19. Sylvestre, D.L., and Ravetch, J.V. 1996. A dominant role for mast cell $\mathrm{Fc}$ receptors in the Arthus reaction. Immunity. 5:387-390.

20. Miyajima, I., et al. 1997. Systemic anaphylaxis in the mouse can be mediated largely through $\operatorname{IgG} 1$ and Fc $\gamma$ RIII. Assessment of the cardiopulmonary changes, mast cell degranulation, and death associated with active or IgE- or IgG1-dependent passive anaphylaxis. J. Clin. Invest. 99:901-914.

21. Dombrowicz, D., et al. 1997. Absence of FcERIa chain results in upregulation of Fc $\gamma$ RIII-dependent mast cell degranulation and anaphylaxis. Evidence of competition between FceRI and Fc $\gamma$ RIII for limiting amounts of $\mathrm{FcR} \beta$ and $\gamma$ chains. J. Clin. Invest. 99:915-925.

22. Finkelman, F.D., Rothenberg, M.E., Brandt, E.B., Morris, S.C., and Strait, R.T. 2005. Molecular mechanisms of anaphylaxis: lessons from studies with murine models. J. Allergy Clin. Immunol. 115:449-457; quiz 458.

23. Williams, C.M., and Galli, S.J. 2000. The diverse potential effector and immunoregulatory roles of mast cells in allergic disease. J. Allergy Clin. Immunol. 105:847-859

24. Boyce, J.A. 2003. The role of mast cells in asthma. Prostaglandins Leukot. Essent. Fatty Acids. 69:195-205.

25. Galli, S.J. 1997. Complexity and redundancy in the pathogenesis of asthma: reassessing the roles of mast cells and T cells. J. Exp. Med. 186:343-347.

26. Humbles, A.A., et al. 2004. A critical role for eosinophils in allergic airways remodeling. Science. 305:1776-1779.

27. Lee, J.J., et al. 2004. Defining a link with asthma in mice congenitally deficient in eosinophils. Science. 305:1773-1776.

28. Miyahara, N., et al. 2004. Effector CD8+ T cells mediate inflammation and airway hyper-responsiveness. Nat. Med. 10:865-869.

29. Djukanovic, R., et al. 2004. Effects of treatment with anti-immunoglobulin E antibody omalizum$\mathrm{ab}$ on airway inflammation in allergic asthma. Am. J. Respir. Crit. Care Med. 170:583-593.

30. Holgate, S., et al. 2005. The anti-inflammatory effects of omalizumab confirm the central role of $\mathrm{IgE}$ in allergic inflammation. J. Allergy Clin. Immunol. 115:459-465.

31. Taube, C., Dakhama, A., and Gelfand, E.W. 2004. Insights into the pathogenesis of asthma utilizing murine models. Int. Arch. Allergy Immunol. 135:173-186

32. Kobayashi, T., et al. 2000. An essential role of mast cells in the development of airway hyperresponsiveness in a murine asthma model. J. Immunol. 164:3855-3861.

33. Williams, C.M., and Galli, S.J. 2000. Mast cells can amplify airway reactivity and features of chronic inflammation in an asthma model in mice. J. Exp. Med. 192:455-462.

34. Taube, C., et al. 2004. Mast cells, Fc epsilon RI, and IL-13 are required for development of airway hyperresponsiveness after aerosolized allergen exposure in the absence of adjuvant. J. Immunol. 172:6398-6406.

35. Takeda, K., et al. 1997. Development of eosinophilic airway inflammation and airway hyperresponsiveness in mast cell-deficient mice. J. Exp. Med. 186:449-454.

36. Henderson, W.R., Jr., et al. 2002. A role for cysteinyl leukotrienes in airway remodeling in a mouse asthma model. Am. J. Respir. Crit. Care Med. 165:108-116.

37. Ikeda, R.K., et al. 2003. Accumulation of peribronchial mast cells in a mouse model of ovalbumin allergen induced chronic airway inflammation: modulation by immunostimulatory DNA sequences. J. Immunol. 171:4860-4867.

38. Kumar, R.K., Herbert, C., and Foster, P.S. 2004. Expression of growth factors by airway epithelial cells in a model of chronic asthma: regulation and relationship to subepithelial fibrosis. Clin. Exp. Allergy. 34:567-575.

39. Marshall, J.S. 2004. Mast-cell responses to pathogens. Nat. Rev. Immunol. 4:787-799.

40. Galli, S.J., Nakae, S., and Tsai, M. 2005. Mast cells in the development of adaptive immune responses. Nat. Immunol. 6:135-142.

41. Ravetch, J.V. 1994. Fc receptors: rubor redux. Cell. 78:553-560.

42. Carlow, D.A., Marth, J., Clark-Lewis, I., and Teh, H.S. 1995. Isolation of a gene encoding a developmentally regulated $\mathrm{T}$ cell-specific protein with a guanine nucleotide triphosphate-binding motif. J. Immunol. 154:1724-1734.

43. Kirkham, S., Sheehan, J.K., Knight, D., Richardson, P.S., and Thornton, D.J. 2002. Heterogeneity of airways mucus: variations in the amounts and glycoforms of the major oligomeric mucins MUC5AC and MUC5B. Biochem. J. 361:537-546.

44. Asai, K., et al. 2001. Regulation of mast cell survival by IgE. Immunity. 14:791-800.
45. Kalesnikoff, J., et al. 2001. Monomeric IgE stimulates signaling pathways in mast cells that lead to cytokine production and cell survival. Immunity. 14:801-811.

46. Kitaura, J., et al. 2003. Evidence that IgE molecules mediate a spectrum of effects on mast cell survival and activation via aggregation of the Fc epsilon RI. Proc. Natl. Acad. Sci. U. S. A. 100:12911-12916.

47. Yamasaki, S., Ishikawa, E., Kohno, M., and Saito, T. 2004. The quantity and duration of FcR gamma signals determine mast cell degranulation and survival. Blood. 103:3093-3101.

48. Kohno, M., Yamasaki, S., Tybulewicz, V.L., and Saito, T. 2005. Rapid and large amount of autocrine IL-3 production is responsible for mast cell survival by $\operatorname{IgE}$ in the absence of antigen. Blood. 105:2059-2065.

49. Wolters, P.J., et al. 2005. Tissue-selective mast cell reconstitution and differential lung gene expression in mast cell-deficient $\mathrm{Kit}^{\mathrm{W}-\mathrm{sh}} / \mathrm{Kit}^{\mathrm{W}-\mathrm{sh}}$ sash mice. Clin. Exp. Allergy. 35:82-88.

50. Grimbaldeston, M.A., et al. 2005. Mast cell-deficient W-sash c-kit mutant Kit $W^{-s h} / W^{-s h}$ mice as a model for investigating mast cell biology in vivo. Am. J. Pathol. 167:835-848.

51. Zhu, D., et al. 2005. A chimeric human-cat fusion protein blocks cat-induced allergy. Nat. Med. 11:446-449.

52. Singer, M., et al. 2004. A MARCKS-related peptide blocks mucus hypersecretion in a mouse model of asthma. Nat. Med. 10:193-196.

53. Humbles, A.A., et al. 2000. A role for the C3a anaphylatoxin receptor in the effector phase of asthma. Nature. 406:998-1001.

54. Krug, N., Tschernig, T., Erpenbeck, V.J., Hohlfeld, J.M., and Kohl, J. 2001. Complement factors C3a and $\mathrm{C} 5 \mathrm{a}$ are increased in bronchoalveolar lavage fluid after segmental allergen provocation in subjects with asthma. Am. J. Respir. Crit. Care Med. 164:1841-1843.

55. Nockher, W.A., and Renz, H. 2006. Neurotrophins and asthma: novel insight into neuroimmune interaction. J. Allergy Clin. Immunol. 117:67-71.

56. Stimler-Gerard, N.P., and Galli, S.J. 1987. Mast cells are not required for anaphylatoxin-induced ileal smooth muscle contraction. J. Immunol. 138:1908-1913.

57. Takai, T., Li, M., Sylvestre, D., Clynes, R., and Ravetch, J.V. 1994. FcR gamma chain deletion results in pleiotrophic effector cell defects. Cell. 76:519-529.

58. Eisenbarth, S.C., et al. 2002. Lipopolysaccharideenhanced, toll-like receptor 4-dependent $\mathrm{T}$ helper cell type 2 responses to inhaled antigen. J. Exp. Med. 196:1645-1651.

59. Martin, T.R., Gerard, N.P., Galli, S.J., and Drazen, J.M. 1988. Pulmonary responses to bronchoconstrictor agonists in the mouse. J. Appl. Physiol. 64:2318-2323.

60. Spergel, J.M., et al. 1998. Epicutaneous sensitization with protein antigen induces localized allergic dermatitis and hyperresponsiveness to methacholine after single exposure to aerosolized antigen in mice. J. Clin. Invest. 101:1614-1622.

61. Savani, R.C., et al. 2000. Bleomycin-induced pulmonary injury in mice deficient in SPARC. Am. J. Physiol. Lung Cell. Mol. Physiol. 279:L743-L750. 